\title{
Patterns in fish species composition and assemblage structure in the upper Salado River lakes, Pampa Plain, Argentina
}

\author{
Juan José Rosso ${ }^{1}$ and Rolando Quirós ${ }^{2 \dagger}$
}

The Pampa Plain, in the central region of Argentina, is mostly drained by the Salado River. The fish fauna of this river is mostly known from field collections in lower reach lakes. Consequently, we aimed to explore the composition and structure of the fish assemblages in the upper Salado River lakes. Patterns in dominance and persistence of species and assemblage level attributes were correlated with environmental and human activity-derived $\left(\mathrm{NO}_{3}: \mathrm{NH}_{4}\right)$ variables. Overall, 19,913 individuals of 17 species included in 5 orders and 11 families were collected. Several species are first records for the upper Salado River lakes. There was a marked proliferation of species in the family Characidae. Conversely, the remainder 10 families were only represented by one or two species. The species composition along the study lakes changed slightly but their relative contribution to the total fish collected (dominance) varied greatly. Rather few species were present in all collections suggesting an important interannual variability in assemblage stability. The gradient in water conductivity was an important factor for the persistence of particular species in the lakes. The gradients in water conductivity and $\mathrm{NO}_{3}: \mathrm{NH}_{4}$ ratio were associated with particular fish communities dominated by different groups of species. These results suggest that even when broad management and conservation strategies should encompass the system as a whole, lake-specific approaches must also be addressed. Overall, our results highlight that human impacts on surface waters may interact with environmental factors to influence the dynamics of fish species and the structure of their communities.

A planície pampeana, na região central da Argentina, é em grande parte drenada pelo rio Salado. A ictiofauna desse rio é conhecida principalmente pelos estudos conduzidos nos lagos dos segmentos inferiores do rio. Em consequência, procuramos examinar a composição e a estrutura das assembleias de peixes dos lagos do alto rio Salado. Os padrões na dominância e persistência das espécies e os atributos das assembleias de peixes foram correlacionados com variáveis ambientais e variáveis indicadoras de perturbações antropogênicas $\left(\mathrm{NO}_{3}: \mathrm{NH}_{4}\right)$. Foram coletados 19913 indivíduos de 17 espécies pertencentes a 5 ordens e 11 famílias. Várias espécies foram registradas pela primeira vez para as lagoas do alto rio Salado. Houve uma marcada proliferação de espécies da família Characidae. Em contraste, as 10 famílias de peixes restantes foram representadas por uma ou duas espécies. A composição de espécies variou pouco ao longo dessas lagoas mas sua contribuição ao total de peixes coletados (dominância) foi muito variável. Poucas espécies estiveram presentes em todas as coletas, sugerindo uma importante variação interanual na estabilidade da assembleia de peixes. O gradiente na condutividade elétrica da água foi importante fator para a persistência de algumas espécies nessas lagoas. A condutividade elétrica da água e o gradiente na relação $\mathrm{NO}_{3}: \mathrm{NH}_{4}$ estiveram associados com assembleias de peixes particulares dominadas por diferentes grupos de espécies. Nossos resultados sugerem que, embora as estratégias de conservação e manejo deveriam considerar o sistema por completo, questões particulares a cada lagoa devem também ser consideradas. Em geral, nossos resultados ressaltam que os impactos humanos nas águas superficiais podem interagir com fatores ambientais para influenciar a dinâmica das espécies de peixes e a estrutura de suas comunidades.

Key words: Environmental gradients, Persistence, Dominance, Diversity, Regional biogeography.

\section{Introduction}

The most recent biogeographical revision of Argentinean fishes (López et al., 2008) classifieds the fish fauna of the Salado River (Buenos Aires province) and its main tributary the Vallimanca stream into the Pampean province, sharing affinities with several drainages of central Argentina. This revision represents a major contribution to fulfil the "blank" in the scenario described in one of the latest synthesis of South America freshwater fish biodiversity (Junk, 2007). In

${ }^{1}$ Centro de Estudios Transdisciplinarios del Agua (CETA), Facultad de Ciencias Veterinarias, Universidad de Buenos Aires. Av. Chorroarín 280, CP1427 Buenos Aires, Argentina. plurosso@yahoo.com.ar

²́rea de Sistemas de Producción Acuática, Departamento de Producción Animal, Facultad de Agronomía, Universidad de Buenos Aires. Av. San Martín 4453, CP 1417 Buenos Aires, Argentina.

'In memoriam to Rolando Quirós who worked with me in the first drafts of this paper. 
spite of that the southern boundary of the Brazilian subregion is located at the Negro River, in Argentina (Almirón et al., 1997) the Salado River basin already represents the southern range of many Neotropical species (Ringuelet, 1975; López et al., 2002). Hence, updated reliable information about patterns in the composition and structure of fish assemblages in this transitional zone is particularly important. Nonetheless, the Salado River fish fauna (López et al., 2001) is mostly known from field collections in lakes at lower segments of its basin (Gómez \& Toresani, 1998). This contrasts with the very few ichthyological investigations that have been conducted at its upper reaches (Mac Donagh, 1934; Ringuelet et al., 1967; Freyre, 1972; Quirós et al., 1988). As consequence, little is known about the actual composition and distribution of the fish fauna in the upper reaches of this river, where major lakes remain largely sub-explored. These lakes are highly fluctuating in salinity and water residence time (Quirós et al., 2002a) and had been largely modified by man and his use of land and water (Quirós et al., 2006).

The assemblage of species that make up fish communities within a river/stream network is attributed mostly to how individual species distributions respond to patterns in vegetated patches (Araujo-Lima et al., 1986; Growns et al., 2003; Pelicice et al., 2008), hydrological connectivity (Amoros \& Bornette, 2002; Petry et al., 2003), water transparency (Rodríguez \& Lewis, 1997; Reyjol et al., 2008; Melo et al., 2009), physicochemical variables (Koné et al., 2003; Barko et al., 2004), food resources availability (Grenouillet \& Pont, 2001), and prey-predator interactions (Piana et al., 2006) among others.

In the upper Salado River lakes, the abundance and distribution of dominant fish species have been shown to mostly follow spatial gradients in water conductivity and anthropogenic factors (Rosso \& Quirós, 2009). However, it was not explored yet whether patterns in dominance and persistence of all fish species in response to these directive gradients may finally influence the richness, diversity and structure of fish assemblages in these lakes. Hence, in this paper our main objective was to addressed two main aspects of the fish fauna of upper Salado River lakes that are still mostly uncover. Firstly, we updated the information about the composition and distribution of the fish fauna. Then, patterns in dominance and persistence of species and assemblage level attributes in relation with major environmental and anthropogenic gradients of the system were explored. These results have strong implications for management and conservation purposes which are discussed accordingly at the end of the paper.

\section{Material and Methods}

\section{Study area}

The Salado River is a lowland river with $690 \mathrm{~km}$ running from 89 meters above sea level in El Chañar Lake (Santa Fe province) and flowing out into the lower reaches of the ParanáPlata basin, at the Samborombón Bay. Together with its main tributaries, the Samborombón River and the Vallimanca Stream, the Salado River encompasses one of the major ecoregions of Central Argentina (López et al., 2002), comprising an area of $179,000 \mathrm{~km}^{2}$. The study lakes are very shallow interconnected natural impoundments located at the headwaters of this river between $34^{\circ} 21^{\prime}$ and $34^{\circ} 42^{\prime} \mathrm{S}$, and $60^{\circ} 39^{\prime}$ and $61^{\circ} 15^{\prime} \mathrm{W}$ (Fig. 1). With a mean surface area ranging from $2 \mathrm{~km}^{2}$ to $50 \mathrm{~km}^{2}$ (Table 1), these lakes are wind mixed, eutrophic to hypereutrophic environments (Quirós et al., 2002a). Due to the high primary productivity by phytoplankton, the extreme turbidity and the habitual anoxia of the water-sediment interface, plant cover in these lakes is minimal and restricted to shallow littoral habitats (Quirós et al., 2002b). Structural complexity (composition and density) of plant cover along shoreline habitats of study lakes is similar (Rosso, pers. obs.) Connectivity between lakes, albeit variable, was always enough to assume a free dispersion of fish among them. Consequently, for the purposes of this paper we disregarded the study of plant cover and connectivity patterns as templates for fish assemblage structure. Conversely, we considered the two main spatial axes along which these lakes may be described; a first axis of landscape human development (Rosso \& Quirós, 2007) and a second abiotic axis of total salinity of their waters (Gabellone et al., 2005). Accordingly to these directive gradients, these lakes display a spatial variation in the $\mathrm{NO}_{3}: \mathrm{NH}_{4}$ ratio and water conductivity respectively (Rosso \& Quirós, 2009).

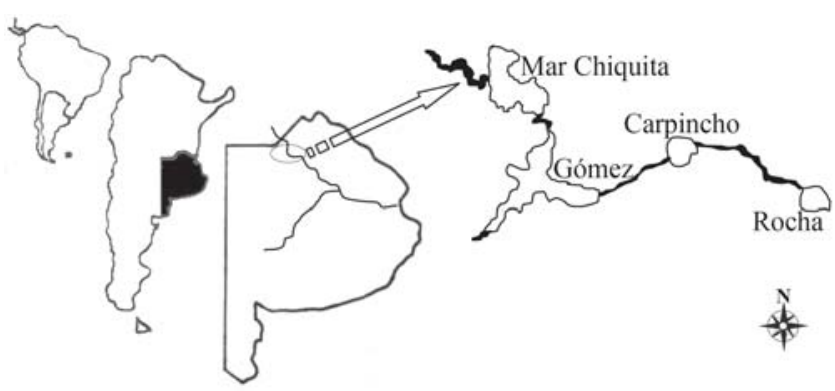

Fig. 1. Schematic diagram of the study area in the upper Salado River, Pampa Plain, Argentina.

\section{Fish sampling}

In order to explore the fish fauna of the upper Salado River lakes monthly samples were taken during two subsequent summers (January to March, 2000 and 2001). Sampling in summer months is aimed to reduce biases in the estimation of species composition due to changes in the seasonal behavior of fishes in relation to the thermal dynamics of waters and photoperiod. Fish collections were made with several fishing gears including seine nets, gill nets and hooklines. Sampling was conducted simultaneously at the littoral and limnetic regions of lakes. In the limnetic areas two multifilament experimental gill nets of ten panels $(15,21,25$, $30,35,40,52,60,75$ and $85 \mathrm{~mm}$ bar mesh size) of equal height $(1.4 \mathrm{~m})$ and length $(10 \mathrm{~m})$ were set during the first two hours of darkness. To capture species in the littoral areas we deployed hook-lines during 4 to 6 hs and hauled a bag seine net constructed with $20 \mathrm{~m}$ long wings (10 mm mesh) and a $2 \mathrm{~m}$ long bag ( $5 \mathrm{~mm}$ mesh) covering $1000 \mathrm{~m}^{2}$ just before sunset. 
Table 1. Mean morphometric and limnological attributes of upper Salado River lakes. Sources: Quirós et al. (1988), Rennella (2007), and Rosso (2008).

\begin{tabular}{lcccccc}
\hline \multicolumn{1}{c}{ Lake } & Area $\left(\mathrm{km}^{2}\right)$ & Depth $(\mathrm{m})$ & Secchi $(\mathrm{cm})$ & Chlorophyll-a $(\mu \mathrm{g} / \mathrm{l})$ & Conductivity $(\mu \mathrm{S} / \mathrm{cm})$ & $\mathrm{NO}_{3}: \mathrm{NH}_{4}$ \\
\hline Mar Chiquita & 50 & 0.9 & 11 & 150.98 & 5925 & 1.13 \\
Gómez & 40 & 1.2 & 19 & 98.88 & 5873 & 0.81 \\
Carpincho & 5 & 1.0 & 21 & 103.12 & 5341 & 0.49 \\
Rocha & 3.6 & 0.8 & 18 & 139.27 & 5200 & 0.28 \\
\hline
\end{tabular}

The effectiveness of these fishing gears as well as the sampling strategy adopted was successfully tested before for these types of lakes (Quirós et al., 1988). Nonetheless, using a large subsequent monthly sampling program in this system (Rosso, 2008) covering seasonal and interannual variation we evaluate if samplings yielded consistent estimates of species composition and relative abundances in all study lakes. All captured fishes were identified in the field (Ringuelet et al., 1967) and counted. The systematic arrangement presented here follows Nelson (2006). Taxonomic synonymies and current status of valid species were checked using the Catalog of Fishes (Eschmeyer \& Fricke, 2008). Comments on geographical distribution of fish species are based on Ringuelet et al. (1967) but updated in accordance to recently published information (Liotta, 2006). Voucher specimens were deposited in the Museo Municipal de Ciencias Naturales "Lorenzo Scaglia” (MMPEAA), at Mar del Plata, Argentina.

\section{Data analysis}

Species composition of each lake was reported as the total number of fish species collected in repeated monthly samples in order to account for eventual variation in patterns of occurrence. With these findings, we discuss the presence and distribution of species in relation with historical reports for these lakes and within the context of regional biogeography. At each lake we computed the total specimens collected of each species as a measure of abundance. Data from hook-lines were only used to complete information on species composition and were not included in the calculation of species abundances. The relative contribution of each species to the total amount of fish collected (expressed in percentage) and their frequencies of occurrence in the samples were estimated. The relative contribution of each species was used as a measure of dominance (Medeiros \& Maltchik, 2001). The frequency of occurrence (as percentage) of each species at each sampling site was computed by dividing the number of samples in which the species was present by the total samples and multiplying by 100 . This was used as a measure of persistence. Fish assemblage richness and diversity (Shannon \& Weaver, 1949) at each lake was also reported.

Patterns in dominance and persistence of species as well as in richness and diversity of fish assemblages in relation with gradients in water conductivity and $\mathrm{NO}_{3}: \mathrm{NH}_{4}$ ratio were explored with Spearman rank correlation coefficients. Summer means of species dominance, assemblage richness and diversity $(n=8)$ plus overall persistence of each species at each lake $(n=4)$ were used for correlation analyses. Information of water conductivity and the $\mathrm{NO}_{3}: \mathrm{NH}_{4}$ ratio was gathered from Rosso \& Quirós (2009). Data were log ( $\mathrm{x}+1)$ transformed prior to analysis.

In field studies, the length of the sampled gradient is important to decide which index of fauna similarity should be applied. The relative weight that is given to abundance information should be larger for short gradients (Lambert \& Dale, 1964). Hence, in order to explore similarity in terms of relative abundance of each species (assemblage structure) we quantified the magnitude of resemblance between fish assemblages of these lakes by performing a similarity percentages analysis (SIMPER) using the Bray-Curtis dissimilarity index as the distance coefficient between two samples. To achieve this we used the corresponding routine in the PRIMER.5 (Plymouth Routines In Multivariate Ecological Research) package. This test also allowed us to identify those species that contribute most to explain dissimilarities between lakes. The relationships between fauna dissimilarity and distance between lakes were explored.

\section{Results}

Overall, 19,913 individuals of 17 species included in 5 orders and 11 families were collected during the surveys. The dominant orders in terms of number of species were Characiformes (41.2\%), and Siluriformes (35.3\%), with seven and six species respectively. Cyprinodontiformes ranked third, with two species (11.7\%) collected in two families, whereas the remainder two orders, Cypriniformes and Atheriniformes, were represented by a single species into a single family, Cyprinidae and Atherinopsidae respectively (Table 2). There was a marked proliferation of species in one family. Conversely, the remainder 10 families were only represented by one or two species. By number of species, the dominant family was Characidae with five members $(29.6 \%)$ followed by Heptapteridae and Loricariidae with two (11.7\%) species. Hence, there were as few as 1.54 species per each family in these freshwater environments of the temperate Pampa Plain.

With this survey, the fish fauna of Rocha Lake was explored for the first time. Furthermore, Cnesterodon decemmaculatus is recorded for the first time in the upper Salado River lakes. This is also the first time that some species are cited for Mar Chiquita, Gómez and Carpincho Lakes. Astyanax fasciatus, Astyanax eigenmanniorum, Bryconamericus iheringii, Cheirodon interruptus, Jenynsia multidentata and Loricariichthys anus are reported for the first time for Mar Chiquita Lake. Three species, Cnesterodon decemmaculatus, Astyanax fasciatus and Astyanax eigenmanniorum are new reports for Gómez Lake whereas Cnesterodon 
Table 2. Systematic list of fish species found in the upper Salado River lakes. MMPEAA: catalog numbers of voucher specimens deposited at the Museo Municipal de Ciencias Naturales "Lorenzo Scaglia”.

\begin{tabular}{lllcc}
\hline \multicolumn{1}{c}{ Order } & \multicolumn{1}{c}{ Family } & \multicolumn{1}{c}{ Fish Taxa } & Species Code & MMPEAA \\
\hline Siluriformes & Heptapteridae & Pimelodella laticeps Eigenmann, 1917 & $\mathrm{Pl}$ & 517 \\
& & Rhamdia quelen (Quoy \& Gaimard, 1824) & $\mathrm{Rq}$ & 518 \\
& Pimelodidae & Parapimelodus valenciennes (Lütken, 1874) & $\mathrm{Pv}$ & 519 \\
& Callichthyidae & Corydoras paleatus (Jenyns, 1842) & $\mathrm{Cp}$ & 520 \\
& Loricariidae & Loricariichthys anus (Valenciennes, 1836) & $\mathrm{La}$ & 521 \\
& & Hypostomus commersoni Valenciennes, 1836 & $\mathrm{Hc}$ & 522 \\
Characiformes & Characidae & Astyanax fasciatus (Cuvier, 1819) & $\mathrm{Af}$ & 523 \\
& & Astyanax eigenmanniorum (Cope, 1894) & $\mathrm{Ae}$ & 524 \\
& & Bryconamericus iheringii (Boulenger, 1887) & $\mathrm{Bi}$ & 525 \\
& & Cheirodon interruptus (Jenyns, 1842) & $\mathrm{Ci}$ & 526 \\
& & Oligosarcus jenynsii (Günther, 1864) & $\mathrm{Oj}$ & 527 \\
& Curimatidae & Cyphocharax voga (Hensel, 1870) & $\mathrm{Cv}$ & 528 \\
Cypriniformes & Erythrinidae & Hoplias malabaricus (Bloch, 1794) & $\mathrm{Hm}$ & 529 \\
Cyprinodontiformes & $\mathrm{Cc}$ & 530 \\
& Cyprinidae & Cyprinus carpio Linnaeus, 1758 & $\mathrm{Jm}$ & 531 \\
Atheriniformes & Anablepidae & Jenynsia multidentata (Jenyns, 1842) & $\mathrm{Cd}$ & 532 \\
& Poeciliidae & Cnesterodon decemmaculatus (Jenyns, 1842) & $\mathrm{Ob}$ & 533 \\
\hline
\end{tabular}

decemmaculatus is the only species that we added to the richest Carpincho Lake. These findings represent an increase of 66, 21 and 6\% for the known ichthyofauna of Mar Chiquita, Gómez and Carpincho Lakes respectively. In these lakes, the diversity of fish assemblages and the species richness varied considerably and were highly related with the gradient in the $\mathrm{NO}_{3}: \mathrm{NH}_{4}$ ratio (Fig. 2). Fish assemblages were significantly richer $(-0.72 ; \mathrm{p}<0.05)$ and more diversified $(-0.93 ; \mathrm{p}<0.01)$ as the $\mathrm{NO}_{3}: \mathrm{NH}_{4}$ decreased.

The fish fauna of these lakes was dominated by open waters planktivore species (Table 3). The most abundant species was the visual planktivore Odontesthes bonariensis followed by the filter planktivore Parapimelodus valenciennis. Both species comprised almost $40 \%$ of total fish collected. These lakes were characterized by a striking low abundance of large piscivores. The top predator Hoplias malabaricus was extremely rare. Similarly, the abundance of Rhamdia quelen was also very low. Conversely, the small carnivore Oligosarcus jenynsii was the most abundant species among the elements that may usually exert some piscivory. Altogether, the abundance of potentially piscivore individuals (carnivores plus piscivores) represented slightly more than $5 \%$ of total fish captured in this river-lakes system. However, if we considered the piscivore Hoplias malabaricus by its own, it only represented on average $0.25 \%$ of total fish collected. Only one species, Cyprinus carpio, is exotic to these temperate waters of Pampa Plain.

Most of the species collected but Hypostomus commersoni, Hoplias malabaricus and Cnesterodon decemmaculatus were present in all lakes. However, their spatial patterns in abundance distribution were highly variable (Fig. 3). Whereas some species seem to be evenly distributed along the study lakes (located around the center of Fig. 3) most of them are highly skewed to either Mar Chiquita and Gómez or Carpincho and Rocha Lakes. Similarly, the dominance of certain species within an assemblage varied from lake to lake. The majority of the species collected dominated most in those lakes where they were more abundant. More than $80 \%$ of the individuals of Odontesthes bonariensis were collected in Mar Chiquita and Gómez Lakes.

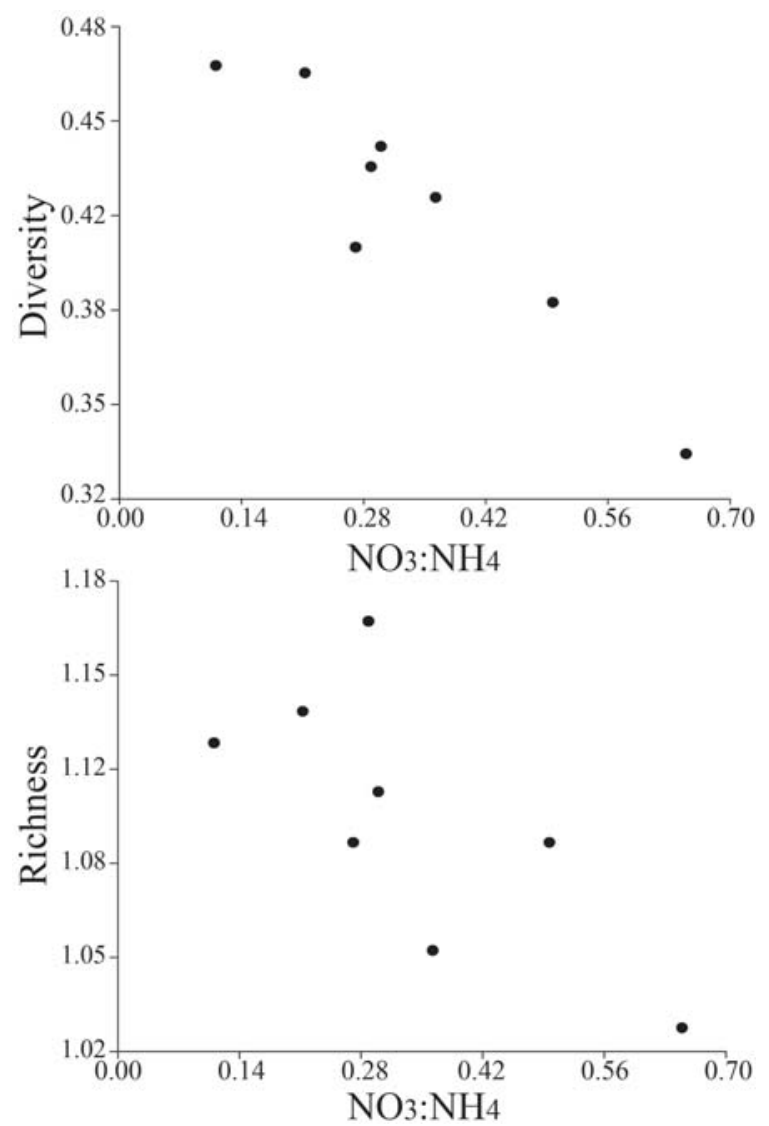

Fig. 2. Relationship between diversity and species richness in fish assemblages and the $\mathrm{NO}_{3}: \mathrm{NH}_{4}$ ratio.

Accordingly, dominance of this species in fish assemblages decreased from Mar Chiquita to Rocha Lakes (Table 3). Similarly, Jenynsia multidentata was extremely skewed to Mar Chiquita and Gómez Lakes with 98\% of their total individuals collected in these environments and contributing with a dominance of more than $10 \%$. The third most abundant species of the system, the detritivorous Cyphocharax voga, was mostly (99\%) captured in Carpincho and Rocha Lakes. Accordingly, the dominance of this species in Mar Chiquita 
Table 3. Number of individuals collected (N), dominance (D) and persistence (P) of fish species in the upper Salado River lakes during summers 2000 and 2001. Dominance and persistence are expressed in percentage. Mch = Mar Chiquita, Go = Gómez, Crp = Carpincho, and Rch $=$ Rocha .

\begin{tabular}{|c|c|c|c|c|c|c|c|c|c|c|c|c|c|c|}
\hline \multirow{2}{*}{ Species } & \multicolumn{3}{|c|}{ Mch } & \multicolumn{3}{|c|}{ Go } & \multicolumn{3}{|c|}{ Crp } & \multicolumn{3}{|c|}{ Rch } & \multicolumn{2}{|c|}{ Total } \\
\hline & $\mathrm{N}$ & $\mathrm{D}$ & $\mathrm{P}$ & $\mathrm{N}$ & $\mathrm{D}$ & $\mathrm{P}$ & $\mathrm{N}$ & $\mathrm{D}$ & $\mathrm{P}$ & $\mathrm{N}$ & $\mathrm{D}$ & $\mathrm{P}$ & $\mathrm{N}$ & $\mathrm{D}$ \\
\hline Parapimelodus valenciennes & 309 & 5.60 & 66 & 967 & 13.84 & 91 & 294 & 10.22 & 100 & 1,085 & 23.93 & 100 & 2,655 & 13.33 \\
\hline Pimelodella laticeps & 16 & 0.29 & 50 & 9 & 0.12 & 25 & 32 & 1.11 & 50 & 49 & 1.08 & 33 & 106 & 0.53 \\
\hline Rhamdia quelen & 4 & 0.07 & 50 & 4 & 0.05 & 41 & 5 & 0.17 & 50 & 1 & 0.02 & 16 & 14 & 0.07 \\
\hline Corydoras paleatus & 742 & 13.45 & 66 & 53 & 0.75 & 41 & 1 & 0.03 & 16 & 9 & 0.19 & 33 & 805 & 4.04 \\
\hline Loricariichthys anus & 2 & 0.03 & 16 & 8 & 0.11 & 58 & 48 & 1.66 & 100 & 3 & 0.06 & 33 & 61 & 0.30 \\
\hline Hypostomus commersoni & 0 & 0 & 0 & 0 & 0 & 0 & 1 & 0.03 & 16 & 0 & 0 & 0 & 1 & 0.01 \\
\hline Astyanax fasciatus & 68 & 1.24 & 100 & 113 & 1.61 & 100 & 189 & 6.56 & 100 & 436 & 9.61 & 100 & 806 & 4.04 \\
\hline Astyanax eigenmanniorum & 199 & 3.61 & 100 & 292 & 4.17 & 100 & 119 & 4.14 & 100 & 99 & 2.19 & 100 & 710 & 3.56 \\
\hline Bryconamericus iheringii & 332 & 6.02 & 100 & 690 & 9.87 & 100 & 199 & 6.90 & 100 & 170 & 3.75 & 100 & 1,391 & 6.98 \\
\hline Cheirodon interruptus & 930 & 16.86 & 100 & 820 & 11.74 & 100 & 159 & 5.52 & 100 & 327 & 7.21 & 100 & 2,235 & 11.22 \\
\hline Oligosarcus jenynsii & 142 & 2.57 & 83 & 285 & 4.07 & 100 & 299 & 10.39 & 100 & 257 & 5.66 & 100 & 983 & 4.93 \\
\hline Cyphocharax voga & 4 & 0.07 & 50 & 16 & 0.22 & 50 & 680 & 23.64 & 100 & 1,579 & 34.82 & 100 & 2,279 & 11.44 \\
\hline Hoplias malabaricus & 0 & 0 & 0 & 1 & 0.01 & 8 & 9 & 0.31 & 50 & 40 & 0.88 & 66 & 50 & 0.25 \\
\hline Cyprinus carpio & 33 & 0.59 & 66 & 29 & 0.41 & 66 & 208 & 7.23 & 100 & 187 & 4.12 & 100 & 457 & 2.29 \\
\hline Jenynsia multidentata & 1,074 & 19.47 & 50 & 990 & 14.17 & 75 & 32 & 1.11 & 83 & 13 & 0.28 & 50 & 2,109 & 10.59 \\
\hline Cnesterodon decemmaculatus & 0 & 0 & 0 & 102 & 1.46 & 100 & 4 & 0.13 & 50 & 7 & 0.15 & 50 & 113 & 0.56 \\
\hline Odontesthes bonariensis & 1,659 & 30.08 & 100 & 2,609 & 37.34 & 100 & 598 & 20.79 & 100 & 272 & 5.99 & 100 & 5,138 & 25.80 \\
\hline Species richness & 14 & & & 16 & & & 17 & & & 16 & & & 17 & \\
\hline Diversity & 1.41 & & & 1.59 & & & 1.81 & & & 1.74 & & & & \\
\hline Total fish collected & 5,515 & & & 6,987 & & & 2,877 & & & 4,534 & & & 19,913 & \\
\hline
\end{tabular}

and Gómez Lakes was less than 1\%. The exotic Cyprinus carpio and the top predator Hoplias malabaricus were mostly confined to Carpincho and Rocha Lakes where their dominances were higher. Dominance of Hoplias malabaricus ranged from $0.01 \%$ in Gómez Lake to $0.88 \%$ in Rocha Lake.

Abundance distributions of other species were also highly skewed to some lakes but their dominance within an assemblage did not changed accordingly. Corydoras paleatus and Pimelodella laticeps showed an opposite spatial distribution (Fig. 3), being the former comparatively more abundant at Mar Chiquita and Gómez Lakes and the latter in Carpincho and Rocha Lakes. Nevertheless, their dominance in any fish assemblage rarely surpassed $1 \%$ (Table 3 ). The dominances of some species were related with gradients in water conductivity and the

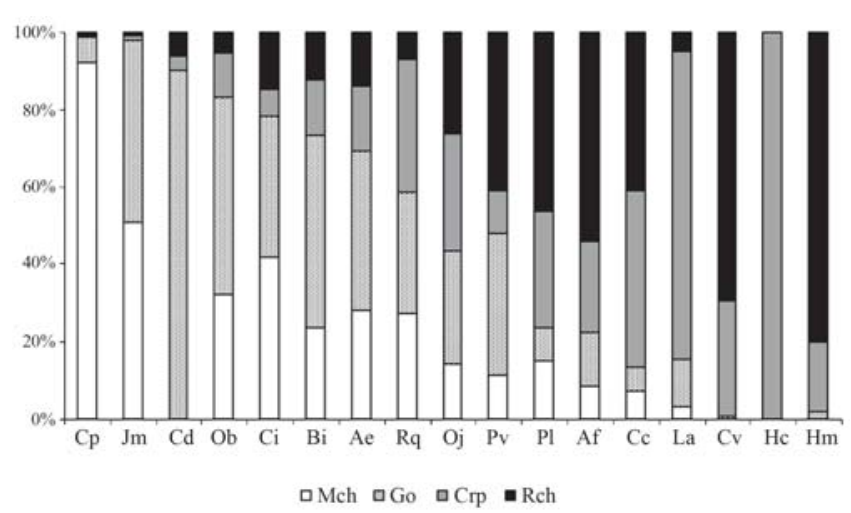

Fig. 3. Bar chart showing the distribution of total fish collected of each species within the upper Salado River lakes. Species codes as listed in Table 2. Species are intentionally sorted by means of their spatial distribution to ease the interpretation. From left to right, from clear to dark filled bars: Mch $=$ Mar Chiquita, Go = Gómez, Crp = Carpincho, and Rch = Rocha .
$\mathrm{NO}_{3}: \mathrm{NH}_{4}$ ratio (Fig. 4). Dominance of Jenynsia multidentata was higher (0.88; $\mathrm{p}<0.01)$ as water conductivity increased whereas the dominance of species such as Cyprinus carpio $(-0.73 ; \mathrm{p}<0.05)$ and Cyphocharax voga $(-0.83 ; \mathrm{p}<0.05)$ were higher when the $\mathrm{NO}_{3}: \mathrm{NH}_{4}$ ratio was lower.

The inland silverside Odontesthes bonariensis together with the small characins Astyanax fasciatus, Astyanax eigenmanniorum, Bryconamericus iheringii and Cheirodon interruptus were present in all collections of each lake (Table 3). The number of species that showed a persistence of $100 \%$ during sampling increased from 5 in Mar Chiquita to 10 and 9 in Carpincho and Rocha Lakes respectively. This increase almost linearly follows the increase in species richness and less intimately in assemblage diversity. Variability in the persistence of some species was related with the gradient in water conductivity. Particularly, persistence in a lake of Cyphocharax voga $(-0.89 ; \mathrm{p}<0.10)$, Parapimelodus valenciennis $(-0.94 ; \mathrm{p}<0.05)$, Hoplias malabaricus $(-0.99$; $\mathrm{p}<0.01)$ and Cyprinus carpio $(-0.89 ; \mathrm{p}<0.10)$ decreased as the water conductivity increased.

The species composition along the study lakes changed slightly but the relative contribution of each species to the total fish collected varied greatly. Dissimilarities in the fish assemblage structure between lakes increased as distance between lakes increased and ranged from as few as $23.48 \%$ (Mar Chiquita - Gómez) to almost 70\% (Mar Chiquita - Rocha). Accordingly, average dissimilarity between Mar Chiquita and Carpincho was intermediate (52.43\%). Average dissimilarity between Gómez and Carpincho (44.48\%) was smaller than Gómez and the more distant Rocha Lake (59.82\%). Finally, percentage dissimilarity between Carpincho and Rocha averaged $30.38 \%$. The percentage dissimilarity between Carpincho and Rocha Lakes with the remainder lakes was always best explained by the relative abundance of 

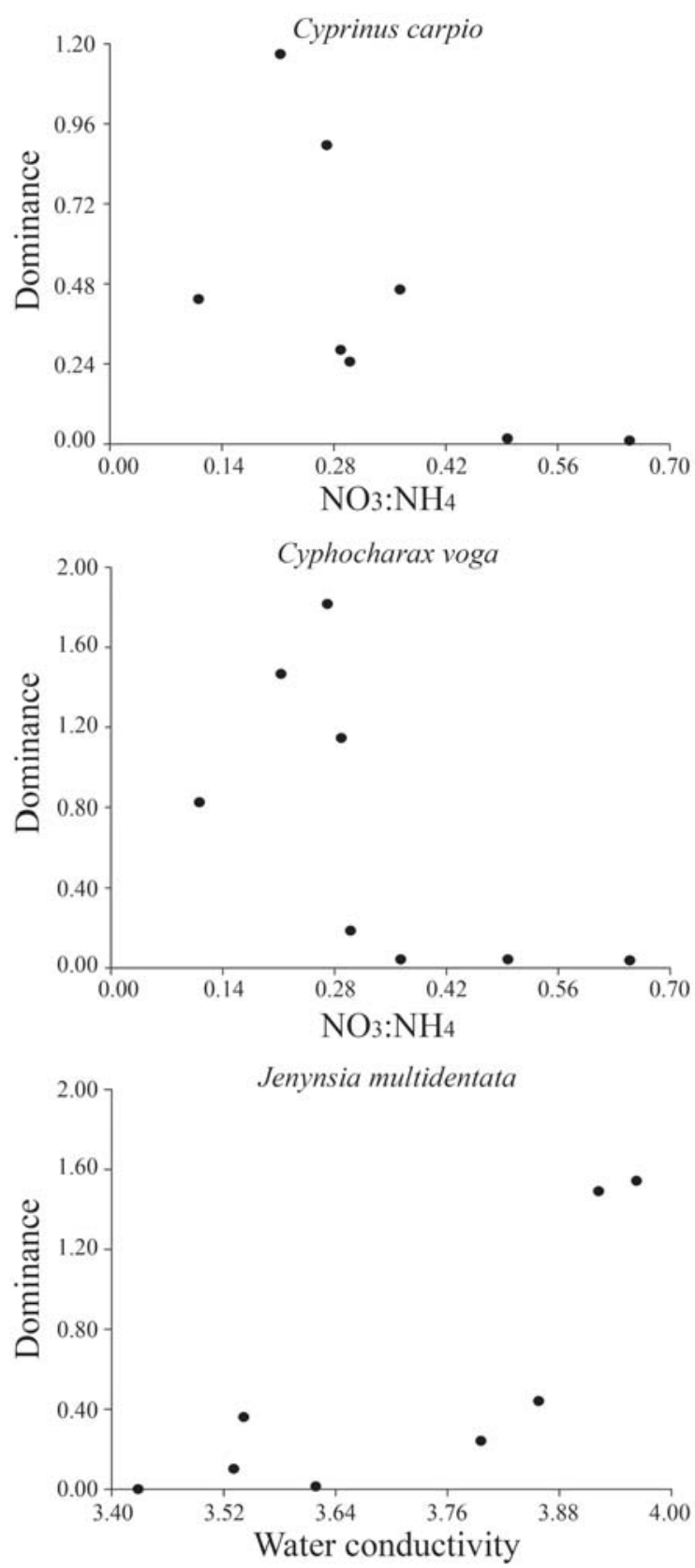

Fig. 4. Relationship between dominance of fish species and gradients in water conductivity and the $\mathrm{NO}_{3}: \mathrm{NH}_{4}$ ratio.

Cyphocharax voga. This species contributed to the total amount of dissimilarity with a percentage ranging from 22.47 to $28.92 \%$. Corydoras paleatus and Jenynsia multidentata, two abundant species in Mar Chiquita Lake, were important elements to explain dissimilarities between this lake and the remainder lakes. All these three species together with Odontesthes bonariensis were the most important elements in explaining dissimilarities between any pair of lakes (Table 4). Combining the individual percentage of these four species it raised to a cumulative contribution averaging near $60 \%$ of the total dissimilarity between lakes. Nevertheless, none species was able to account for more than $30 \%$ of the percentage dissimilarity between lakes.

\section{Discussion}

In the upper Salado River lakes, species from Characiformes and Siluriformes orders made up more than $75 \%$ of the total fish fauna. This is a constant pattern of fish assemblage organization for most freshwater environments of South America (Lowe-McConnell, 1987; Rodríguez \& Lewis, 1990; Pouilly et al., 1999). Nonetheless, when entering into the Pampa Plain, the contribution of Characiformes and Siluriformes to fish assemblages diminishes sharply. In the Salado River basin as a whole both orders represent the 64\% of total species (López et al., 2001) but further inland, when occasional visitors from lower Salado River are "filtered", its contribution to the whole assemblage drops to 53\% (Rosso, 2006). This has been considered as a transitional process of change in assemblage organization towards the Austral subregion (Ringuelet, 1975).

\section{Historical records and regional biogeography of species}

The pioneer study of Mac Donagh (1934) and later contributions of Ringuelet et al. (1967), Quirós et al. (1988), López et al. (2001), plus a series of unpublished reports available at Dirección Provincial de Pesca (2008), constitute the reference for the known ichthyofauna of the upper Salado River lakes. Overall, these studies reported 9 species in Mar Chiquita Lake, 14 in Gómez Lake and 16 in Carpincho Lake. None effort had ever been directed until this paper to study the fish fauna of Rocha Lake. Besides the presence of Hypostomus commersoni in Mar Chiquita and Gómez Lakes (Dirección Provincial de Pesca, 2008), all species previously cited for the upper Salado River lakes were registered in our samples.

Most of the species that we collected in the upper Salado River lakes are widely distributed along the entire Pampa Plain (López et al., 2002). Conversely, Parapimelodus valenciennis, Loricariichthys anus and Hypostomus commersoni are mostly restricted to the Salado River basin (Rosso, 2006). Parapimelodus valenciennis, which nowadays represents the second most abundant species in the upper Salado River lakes, was cited for the first time in this system by the year 1934 in Carpincho Lake (Mac Donagh, 1934). However, subsequent samplings during the next decades did not report this species in these lakes (Ringuelet et al., 1967; Quirós et al., 1988). By the year 2000 this species was reported again for the upper Salado River lakes when was collected in Gómez Lake (Dirección Provincial de Pesca, 2008). The intermittent presence of Parapimelodus valenciennis in the upper Salado River lakes could be the result of the use by this species of the main course of the Salado River as an important corridor for displacements between lakes. For instance, an upstream migration from lower reaches lakes as a source of this species for the upper river lakes might be possible. Indeed, when Ringuelet et al. (1967) explored the Salado River basin this silurid was absent in the upper lakes but was conspicuously found in lower reaches lakes. This suggest that in the past it is quite probable that lower reach lakes behaved as "source habitats" (sensu Pulliam, 1988) for Parapimelodus 
Table 4. Similarity Percentage Analysis detailing individual (Contrib \%) and cumulative (Acum \%) contribution of each species for all between lakes comparisons. Mch = Mar Chiquita, Go = Gómez, Crp = Carpincho, and Rch $=$ Rocha. Species codes as listed in Table 2.

\begin{tabular}{|c|c|c|c|c|c|c|c|c|}
\hline Mch vs. Go & Contrib \% & Acum $\%$ & Go vs. Crp & Contrib \% & Acum \% & Rch vs. Crp & Contrib $\%$ & Acum \% \\
\hline Cp & 27.01 & 27.01 & $\mathrm{Cv}$ & 26.31 & 26.31 & $\mathrm{Ob}$ & 24.33 & 24.33 \\
\hline $\mathrm{PV}$ & 17.53 & 44.55 & $\mathrm{Ob}$ & 18.60 & 44.91 & Pv & 22.56 & 46.89 \\
\hline $\mathrm{Ob}$ & 15.43 & 59.97 & $\mathrm{Jm}$ & 14.67 & 59.58 & $\mathrm{Cv}$ & 18.42 & 65.31 \\
\hline $\mathrm{Jm}$ & 11.31 & 71.29 & Cc & 7.66 & 67.24 & Oj & 7.78 & 73.09 \\
\hline $\mathrm{Ci}$ & 10.93 & 82.22 & Oj & 7.10 & 74.34 & $\mathrm{Bi}$ & 5.21 & 78.30 \\
\hline $\mathrm{Bi}$ & 8.20 & 90.43 & $\mathrm{Ci}$ & 6.98 & 81.32 & Cc & 5.11 & 83.41 \\
\hline Oj & 3.20 & 93.63 & Af & 5.58 & 86.90 & Af & 5.01 & 88.42 \\
\hline Cd & 3.11 & 96.73 & $\mathrm{Pv}$ & 4.07 & 90.97 & Ae & 3.21 & 91.63 \\
\hline $\mathrm{Ae}$ & 1.21 & 97.95 & $\mathrm{Bi}$ & 3.32 & 94.29 & $\mathrm{Ci}$ & 2.77 & 94.40 \\
\hline Af & 0.79 & 98.73 & $\mathrm{La}$ & 1.75 & 96.04 & $\mathrm{La}$ & 2.64 & 97.04 \\
\hline Cc & 0.39 & 99.12 & $\mathrm{Cd}$ & 1.48 & 97.52 & $\mathrm{Jm}$ & 1.36 & 98.40 \\
\hline $\mathrm{Pl}$ & 0.34 & 99.47 & $\mathrm{Pl}$ & 1.11 & 98.63 & $\mathrm{Hm}$ & 0.94 & 99.34 \\
\hline $\mathrm{Cv}$ & 0.33 & 99.80 & Ср & 0.83 & 99.46 & Ср & 0.27 & 99.61 \\
\hline $\mathrm{La}$ & 0.17 & 99.97 & $\mathrm{Hm}$ & 0.34 & 99.80 & $\mathrm{Rq}$ & 0.25 & 99.86 \\
\hline $\mathrm{Hm}$ & 0.03 & 100 & $\mathrm{Rq}$ & 0.11 & 99.91 & Нc & 0.06 & 99.92 \\
\hline $\mathrm{Rq}$ & 0 & 100 & $\mathrm{Ae}$ & 0.05 & 99.96 & $\mathrm{Pl}$ & 0.05 & 99.97 \\
\hline Hc & 0 & 100 & Нc & 0.04 & 100 & $\mathrm{Cd}$ & 0.03 & 100 \\
\hline \multicolumn{9}{|c|}{ Mch vs. Crp Contrib \% Acum \% Go vs. Rch Contrib \% Acum \% Rch vs. Mch Contrib \% Acum \% } \\
\hline $\mathrm{Cv}$ & 22.47 & 22.47 & $\mathrm{Cv}$ & 28.92 & 28.92 & $\mathrm{Cv}$ & 24.85 & 24.85 \\
\hline $\mathrm{Jm}$ & 17.51 & 39.98 & $\mathrm{Ob}$ & 26.19 & 55.11 & $\mathrm{Ob}$ & 17.22 & 42.07 \\
\hline Ср & 12.80 & 52.78 & $\mathrm{Jm}$ & 11.60 & 66.71 & $\mathrm{Jm}$ & 13.72 & 55.79 \\
\hline $\mathrm{Ci}$ & 10.81 & 63.59 & $\mathrm{Pv}$ & 8.44 & 75.15 & $\mathrm{Pv}$ & 13.10 & 68.89 \\
\hline $\mathrm{Ob}$ & 8.87 & 72.46 & Af & 6.70 & 81.85 & Сp & 9.48 & 78.37 \\
\hline $\mathrm{Oj}$ & 7.46 & 79.92 & $\mathrm{Bi}$ & 5.12 & 86.97 & $\mathrm{Ci}$ & 6.90 & 85.27 \\
\hline Cc & 6.32 & 86.24 & $\mathrm{Ci}$ & 3.78 & 90.75 & Af & 5.99 & 91.26 \\
\hline Af & 5.09 & 91.33 & Cc & 3.10 & 93.85 & Cc & 2.52 & 93.78 \\
\hline $\mathrm{Pv}$ & 4.40 & 95.73 & $\mathrm{Ae}$ & 1.67 & 95.52 & Oj & 2.21 & 95.99 \\
\hline $\mathrm{La}$ & 1.56 & 97.29 & Oj & 1.33 & 96.85 & $\mathrm{Bi}$ & 1.62 & 97.61 \\
\hline $\mathrm{Bi}$ & 0.85 & 98.14 & Cd & 1.09 & 97.94 & $\mathrm{Ae}$ & 1.02 & 98.63 \\
\hline $\mathrm{Pl}$ & 0.78 & 98.92 & $\mathrm{Pl}$ & 0.80 & 98.74 & $\mathrm{Hm}$ & 0.63 & 99.26 \\
\hline $\mathrm{Ae}$ & 0.50 & 99.42 & $\mathrm{Hm}$ & 0.73 & 99.47 & $\mathrm{Pl}$ & 0.57 & 99.83 \\
\hline $\mathrm{Hm}$ & 0.30 & 99.72 & Cp & 0.48 & 99.95 & Cd & 0.11 & 99.94 \\
\hline $\mathrm{Cd}$ & 0.13 & 99.85 & $\mathrm{Rq}$ & 0.04 & 99.99 & $\mathrm{Rq}$ & 0.04 & 99.98 \\
\hline $\mathrm{Rq}$ & 0.10 & 99.95 & $\mathrm{La}$ & 0.04 & 100 & $\mathrm{La}$ & 0.02 & 100 \\
\hline Hc & 0.03 & 100 & Hc & 0 & 100 & Hc & 0 & 100 \\
\hline
\end{tabular}

valenciennis. The same could be happening in the present with Hypostomus commersoni, a commonly abundant species in lower basin lakes. A very few individuals of this species had been collected for the first time in the upper reach lakes lately (Dirección Provincial de Pesca, 2008; this paper). The expansion in the distribution of this species within the middle and lower Salado River reaches from 1957 to present was suspected to be related with changes in pluviosity, temperature and channelization (Gómez, 2008). In the case of Parapimelodus valenciennis, it has been shown that temporal variability in the water residence time and water salinity affect the distribution range of this species (Rosso \& Quirós, 2009).

With this work we enlarge the distribution range of several species that have been cited for the first time in the upper Salado River lakes. Particularly, this is the first time that Cnesterodon decemmaculatus is collected in these lakes. This small cyprinodontiform was cited three times in the Salado River, but always at lower reaches of the basin in Chascomús, Vitel and Lobos Lakes (López et al., 2001). This species seems to be more conspicuous in the southern Atlantic drainages of the Pampa Plain (Casciotta et al., 1999).

From source to sea, there is a worldwide pattern of gradual increase in fish species richness in riverine environments, intimately associated to a longitudinal gradient in environmental, hydrological and topographic conditions. This was early highlighted for steeped temperate rivers in North America (Burton \& Odum, 1945), Europe (Huet, 1949) and South America (Petry \& Schulz, 2006). This pattern was also revealed in tropical fluvial ecosystems where altitudinal gradient seems to be one of the most important factors determining fish species distribution (Hoeinghaus et al., 2004; Súarez \& Petrere Júnior, 2007). Under such conditions, in spite of the higher number of species at lower reaches, some fish species occur exclusively at headwaters whereas others occur exclusively at downstream. Comparing the updated taxonomic list that we presented here with the fish fauna of middle and lower reach lakes of the Salado River (López et al., 2001) allowed us to realize that species composition along the longitudinal axis of this river changes exclusively by species addition instead of substitution. This finding contrasts with the worldwide pattern observed in lotic ecosystems. Nonetheless, if we consider the fish fauna of the Quinto River, which in the past was connected with the headwaters of the Salado River (Siragusa, 1964), the traditional scenario of longitudinal distribution of fish species is achieved with the exclusive presence of Trichomycterus corduvensis and Trichomycterus tenuis (Ringuelet, 1975). 


\section{Patterns in species richness and assemblage diversity}

The species richness in a particular freshwater environment may be interpreted as the result of a process in which the global pool of fish species must face a series of filters (Smith \& Powell, 1971). Following this concept we may assume that once the species "reached" the upper Salado River lakes in the past, they dispersed among them following major environmental gradients in relation with their autoecology. Indeed, one striking feature of this system is its unusual high concentrations of sodium chloride derived from a sedimentary aquifer located in its headwaters, which originated during arid periods of the Pleistocene (Gabellone et al., 2005). It is quite probably, therefore, that this factor had historically filtered much of the potential regional fauna and forced those species able to reach these waters to disperse in accordance with their tolerance to salinity. Further in the present, the interactive effects of salinity with anthropogenic impacts and hydrological variability impose additional directive forces for some species (Rosso \& Quirós, 2009). Precisely, this study shows that the effects derived from anthropogenic releases (as indicated by the $\mathrm{NO}_{3}: \mathrm{NH}_{4}$ ratio) are highly important for the richness and diversity of the fish assemblage at a particular locality.

In this study we also found evidence that linked persistence of species with richness and to a lesser extent with diversity of fish assemblages. Particularly, our results suggest that assemblages where more fish species seem to be highly persistent (100\%) are prone to be richer and more diverse or vice versa. These findings partially agree with an historical view in ecology that postulated that diversity begets stability (Odum, 1953; Elton, 1966). In this sense, richer and more diverse assemblages of these lakes should be more stable since they have a larger number of species with high persistence in the environment. However, persistence of species is just one component of stability. Stability is really a meta-concept that covers a range of different properties and components of the ecosystem (Loreau et al., 2002). In our study, regardless the relative few sampling months, rather few species were present in all collections at any lake (Table 3) suggesting an important interannual variability in assemblage stability as indicated by persistence of species.

\section{Dominance, persistence and assemblage structure}

Following observed patterns in persistence and dominance of species, we may assume that not all these lakes seemed to be equally favorable environments to most of the fish species present in the upper Salado River basin. Fishes are mobile organisms that actively select the optimum between a pool of habitats (Karr, 1981). It could be expected, therefore, that the abundance of each species should be larger near its optimum suite of environmental conditions. Similarly, for those species with wider tolerance for environmental variables, we should expect they would dominate most near the limit of its distribution range, where the suite of more extreme environmental conditions probably exclude less tolerant species. Indeed, the significant association between dominance of Jenynsia multidentata and gradient in water conductivity is in accordance with the well known tolerance of this Cyprinodontiformes to high salinity (Thormälen de Gil, 1949; Menni et al., 1996). Similarly, the finding that dominances of Cyphocharax voga and Cyprinus carpio were negatively aligned with gradient in $\mathrm{NO}_{3}: \mathrm{NH}_{4}$ ratio, agrees with previous results that highlighted how these two species are favored by organically impacted (low $\mathrm{NO}_{3}: \mathrm{NH}_{4}$ ) environments, whereas other species found these conditions largely disadvantageous (Rosso \& Quirós, 2009). The present paper also revealed how these environmental gradients are important for the persistence of particular species at particular sites. In northern temperate streams (see review in Matthews, 1998) the more abundant species at a locality are typically persistent and only some rarer species are nonpersistent. Similarly, in the upper Salado River lakes, the persistence of species as Parapimelodus valenciennis, Cyprinus carpio, Cyphocharax voga and Hoplias malabaricus varied greatly between lakes but was higher in those lakes where these species were more abundant and tended to dominate most. Particularly, the persistence of these four species in a lake seemed to be negatively affected by water conductivity.

In spite of the high proximity between lakes and the short spatial gradient explored, different patterns in dominance and persistence of many species leaded to an important variation in fish assemblage structure. Exploration of fish assemblages along a short spatial scale in the uppermost part of the Paraná River also demonstrated a great ichthyofauna heterogeneity (Fialho et al., 2007). In our study, with only four species, the similarity percentage analysis was able to explain almost $60 \%$ of the total dissimilarity between any pair of lakes. Thus, Corydoras paleatus, Jenynsia multidentata, Cyphocharax voga and Odontesthes bonariensis may be considered as key species for the distinctiveness between the upper Salado River lakes.

Overall, we have shown that the gradient in water conductivity is an important factor for the persistence of particular species in a particular location. This study also highlighted that gradients in water conductivity and the $\mathrm{NO}_{3}: \mathrm{NH}_{4}$ ratio set up particular conditions that were associated with particular fish communities dominated by different groups of species. All these results show that human impacts on surface waters may interact with environmental factors to influence the dynamics of fish species and the structure of their communities. In comparison, the extremely low abundance of piscivores suggests that predation would play a minor role in these fish assemblages.

\section{Implications for management and conservation}

In this paper, we identified those species that contribute most to the distinctiveness of each lake in the upper Salado River basin. These findings are of practical interest for management and conservation purposes. Particularly, the contracted spatial distribution of locally abundant species, as Odontesthes bonariensis and Cyphocharax voga, should be addressed as an important issue for fisheries regulations. 
Similarly, conservation efforts should be enforced towards those less abundant species that are, as well, mostly confined to a shorter spatial habitat. Among these species major efforts should be focused on Cnesterodon decemmaculatus in Gómez Lake, loricariids in Carpincho Lake and finally, on the top predator Hoplias malabaricus which was almost exclusively found in Rocha Lake. Likewise, control plans for the exotic Cyprinus carpio should be mostly centered around Carpincho and Rocha Lakes, where this species is more abundant. These results demonstrate that even when broad management and conservation strategies should encompass the system as a whole, lake-specific approaches must also be addressed.

\section{Acknowledgements}

Authors acknowledge research support from Consejo Nacional de Investigaciones Científicas y Técnicas (CONICET) and Agencia Nacional de Promoción Científica y Tecnológica (SECyT). We thank Cristián Petracchi, Hugo von Bernard and Daniel Blanco Bello for their assistance. We also thank Javier Villamil, Rodrigo Porta, Marcelo and Daniel Cufré and Municipalidad de Junín for their collaboration in field sampling. Guillermo A. Bentivegna collaborated with figure edition. Juan José Rosso wishes to recognize the labor of Lic. María Gabriela Pujol in the Museo Municipal de Ciencias Naturales “Lorenzo Scaglia”.

\section{Literature Cited}

Almirón, A. E., M. Azpelicueta, J. R. Casciotta \& A. López Cazorla. 1997. Ichthyogeographic boundaries between the Brazilian and Austral subregions in South America, Argentina. Biogeographica, 73: 23-30.

Amoros, C. \& G. Bornette. 2002. Connectivity and biocomplexity in waterbodies of riverine floodplains. Freshwater Biology, 47: 761-776.

Araujo-Lima, C. A., L. Portugal \& E. Ferreira. 1986. Fish-macrophyte relationship in Anavilhanas Archipelago, a black water system in the central Amazon. Journal of Fish Biology, 29: 1-11.

Barko, V. A., D. P. Herzog, R. A. Hrabik \& J. S. Scheibe. 2004. Relationship among fish assemblages and main-channel-border physical habitats in the unimpounded upper Mississippi River. Transactions of the American Fisheries Society, 133(2): 371384.

Burton, G. W. \& E. P. Odum. 1945. The distribution of stream fish in the vicinity of Mountain Lake, Virginia. Ecology, 26: 182-194.

Casciotta, J. R., A. Almirón, A. Cione \& M. M. Azpelicueta. 1999. Brazilian freshwater fish assemblages from southern pampean area, Argentina. Biogeographica, 75(2): 67-78.

Dirección Provincial de Pesca. 2008. Informes biológicos-pesqueros continentales. Ministerio de Asuntos Agrarios, Provincia de Buenos Aires. Available from: http://www.maa.gba.gov.ar/pesca/informesbiolpesque_continentales.php\#08 (Accessed in August 12, 2009).

Elton, C. S. 1966. The pattern of animal communities. London, Methuen, 432p.

Eschmeyer, W. N. \& R. Fricke. 2008. Catalog of fishes. Electronic version. Available from: http://research.calacademy.org/ichthyology/ catalog/fishcatsearch.html (Accessed in December 18, 2008).
Fialho, A. P., L. G. Oliveira, F. L. Tejerina-Garro \& L. C. Gomes. 2007. Fish assemblage structure in the tributaries of the Meia Ponte River, Goiás, Brazil. Neotropical Ichthyology, 5(1): 5360.

Freyre, L. R. 1972. Pollution of the "El Carpincho" pond (Pampasic Region, Argentina) and its effects on plankton and fish communities. Environmental Pollution, 4: 37-40.

Gabellone, N. A., M. C. Claps, L. C. Solari \& N. C. Neschuk. 2005. Nutrients, conductivity and plankton in a landscape approach to a Pampean saline lowland river (Salado River, Argentina). Biogeochemistry, 75: 455-477.

Gómez, S. E. 2008. Notas sobre el cambio ambiental en ictiología. Biología Acuática, 24: 1-6.

Gómez, S. E. \& N. I. Toresani. 1998. Pampas. Pp. 97-114. In: Canevari, P., D. E. Blanco, E. Bucher, G. Castro \& I. Davidson (Eds.). Los humedales de la Argentina: Clasificación, situación actual, conservación y legislación. Buenos Aires, Wetlands International Publication, 46, 208p.

Grenouillet, G. \& D. Pont. 2001. Juvenile fishes in macrophyte beds: influence of food resources, habitat structure and body size. Journal of Fish Biology, 59: 939-959.

Growns, I., P. C. Gehrke, K. L. Astles \& D. A. Pollard. 2003. A comparison of fish assemblages associated with different riparian vegetation types in the Hawkesbury-Nepean River system. Fisheries Management and Ecology, 10: 209-220.

Hoeinghaus, D. J., K. O. Winemiller \& D. C. Taphorn. 2004. Compositional change in fish assemblages along the Andean piedmont - Lhanos floodplain gradient of the río Portuguesa, Venezuela. Neotropical Ichthyology, 2(2): 85-92.

Huet, M. 1949. Aperçu des relations entre la pente et les populations piscicoles des eaux courantes. Swiss Journal of Hydrology, 11: 333-351.

Junk, W. J. 2007. Freshwater fishes of South America: Their biodiversity, fisheries, and habitats - a synthesis. Aquatic Ecosystem Health \& Management, 10(2): 228-242.

Karr, J. R. 1981. Assessment of biotic integrity using fish communities. Fisheries, 6: 21-27.

Koné, T., G. G. Teugels, V. N. Douba, E. P. Kouamélan \& G. Gooré $\mathrm{Bi}$. 2003. Fish assemblages in relation to environmental gradients along a small west African coastal basin, the San Pedro River, Ivory Coast. African Journal of Aquatic Science, 28(2): 163-168.

Lambert, J. M. \& M. B. Dale. 1964. The use of statistics in phytosociology. Advances in Ecological Research, 2: 59-99.

Liotta, J. 2006. Distribución geográfica de los peces de aguas continentales de la República Argentina. ProBiota, Serie Documentos $\mathrm{N}^{\circ}$ 3. Buenos Aires, FCNyM, UNLP, 701p.

López, H. L., C. Baigún, J. Iwaszkiw, R. Delfino \& O. Padín. 2001. La Cuenca del Salado: Uso y Posibilidades de sus Recursos Pesqueros. La Plata, EDULP, 60p.

López, H. L., R. C. Menni, M. Donato \& A. M. Miquelarena. 2008. Biogeographical revision of Argentina (Andean and Neotropical Regions): an analysis using freshwater fishes. Journal of Biogeography, 35(9): 1564-1579.

López, H. L., C. C. Morgan \& M. J. Montenegro. 2002. Ichthyological ecoregions of Argentina. Documents Series, ProBiota, on line version (ISSN 1666-7328).

Loreau, M., A. Downing, M. Emmerson, A. Gonzalez, J. Hughes, P. Inchausti, J. Joshi, J. Norberg \& O. Sala. 2002. A new look at the relationship between diversity and stability. Pp. 79-91. In: Loreau, M., S. Naeem \& P. Inchausti (Eds.). Biodiversity and Ecosystem Functioning: Synthesis and Perspectives. Oxford, Oxford University Press, 312p. 
Lowe-McConnell, R. H. 1987. Ecological studies in tropical fish communities. Cambridge, Cambridge University Press, 382p.

Mac Donagh, E. 1934. Nuevos conceptos sobre distribución geográfica de los peces argentinos basados en expediciones del Museo de La Plata. Revista del Museo de La Plata, Argentina, 34: 21-170.

Matthews, W. J. 1998. Patterns in freshwater fish ecology. London, Chapman \& Hall, 756p.

Medeiros, E. S. F. \& L. M. Maltchik. 2001. Diversity and stability of fishes (Teleostei) in a temporary river of the Brazilian semiarid region. Iheringia, Série Zoologia, 90: 157-166.

Melo, C. E. de, J. D. Lima \& E. F. da Silva. 2009. Relationships between water transparency and abundance of Cynodontidae species in the Bananal floodplain, Mato Grosso, Brazil. Neotropical Ichthyology, 7(2): 251-256.

Menni, R. C., S. E. Gómez \& F. López Armengol. 1996. Subtle relationships: freshwater fishes and water chemistry in southern South America. Hidrobiologia, 328: 173-197.

Nelson, J. S. 2006. Fishes of the world. Fourth edition. Hoboken, New Jersey, John Wiley \& Sons, 601p.

Odum, E. P. 1953. Fundamentals of Ecology. Philadelphia, W. B. Saunders, 574p.

Pelicice, F. M., S. M. Thomaz \& A. A. Agostinho. 2008. Simple relationships to predict attributes of fish assemblages in patches of submerged macrophytes. Neotropical Ichthyology, 6(4): 543550.

Petry, A. C., A. A. Agostinho \& L. C. Gomes. 2003. Fish assemblages of tropical floodplain lagoons: exploring the role of connectivity in a dry year. Neotropical Ichthyology, 1(2): 111-119.

Petry, A. C. \& U. H. Schulz. 2006. Longitudinal changes and indicator species of the fish fauna in the subtropical Sinos River, Brazil. Journal of Fish Biology, 69: 272-290.

Piana, P. A., L. C. Gomes \& E. M. Cortez. 2006. Factors influencing Serrapinnus notomelas (Characiformes: Characidae) populations in upper Paraná river floodplain lagoons. Neotropical Ichthyology, 4(1): 81-86.

Pouilly, M., C. Ibañez, M. Gutierrez \& T. Yunoki. 1999. Funcionamiento ecológico de las lagunas de la zona de inundación del Río Mamoré (Beni-Bolivia). Revista Boliviana de Ecología y Conservación, 6: 41-54.

Pulliam, H. R. 1988. Sources, sinks and population regulation. The American Naturalist, 132: 652-661.

Quirós, R., C. R. M. Baigún, S. Cuch, R. Delfino, A. de Nichilo, C. Guerrero, M. C. Marinone, S. Menu Marque \& M. C. Scapini. 1988. Evaluación del rendimiento pesquero potencial de la República Argentina I: Datos 1. Informes Técnicos del Departamento de Aguas Continentales. Buenos Aires, Instituto Nacional de Investigación y Desarrollo Pesquero, Informe Técnico, 7, 55p.

Quirós, R., M. B. Boveri, C. A. Petracchi, A. M. Rennella, J. J. Rosso \& A. Sosnovsky. 2006. The effects of the pampa wetlands agriculturization on shallow lakes eutrophication. Pp. 1-16. In: Tundisi, J. G., T. Matsumura-Tundisi \& C. Sidagis Galli (Eds.). Eutrofização na América do Sul: Causas, conseqüências e tecnologias de gestão. São Carlos, Rede EUTROSUL, PROSUL.

Quirós, R., A. M. Rennella, M. Boveri, J. J. Rosso \& A. Sosnovsky. 2002a. Factores que afectan la estructura y el funcionamiento de las lagunas pampeanas. Ecología Austral, 12: 175-185.

Quirós, R., J. J. Rosso, A. M. Rennella, A. Sosnovsky \& M. B. Boveri. 2002b. Análisis del estado trófico de las lagunas pampeanas (Argentina). Interciencia, 27(11): 584-591.
Rennella, A. 2007. Relevancia de las interacciones tróficas en la determinación de la estructura del zooplancton en grandes lagunas pampeanas. Unpublished Ph.D. Dissertation, Universidad de Buenos Aires, Buenos Aires, 115p.

Reyjol Y., M. A. Rodríguez, N. Dubuc, P. Magnan \& R. Fortin. 2008. Among- and within-tributary responses of riverine fish assemblages to habitat features. Canadian Journal of Fisheries and Aquatic Sciences, 65(7): 1379-1392.

Ringuelet, R. A. 1975. Zoogeografía y ecología de los peces de agua continentales de Argentina y consideraciones sobre las áreas ictiológicas de América del Sur. Ecosur, 2(3): 1-122.

Ringuelet, R. A., R. H. Arámburu \& A. Alonso de Arámburu. 1967. Los peces argentinos de agua dulce. La Plata, Comisión de Investigaciones Científicas de la Provincia de Buenos Aires (CIC), 602p.

Rodríguez, M. A. \& W. M. J. Lewis. 1990. Diversity and species composition of fish communities of Orinoco floodplain lakes. National Geographic Research, 6: 319-328.

Rodríguez, M. A. \& W. M. J. Lewis. 1997. Structure of fish assemblages along environmental gradients in floodplain lakes of the Orinoco River. Ecological Monographs, 67: 109-128.

Rosso, J. J. 2006. Peces pampeanos: guía y ecología. Buenos Aires, Literature of Latin America, 224p.

Rosso, J. J. 2008. Relación entre la abundancia y estructura de la comunidad de peces y el régimen hidrológico en lagunas de la alta cuenca del río Salado. Unpublished Ph.D. Dissertation, Universidad de Buenos Aires, Buenos Aires, 97p.

Rosso, J. J. \& R. Quirós. 2007. Exploring relationships among hydrology, human disturbance and fish abundance in a series of very shallow lowland river lakes. Pp. 1264-1272. Cochabamba, Proceedings of Multi-level and Multi-scale Sustainability Congress.

Rosso, J. J. \& R. Quirós. 2009. Interactive effects of abiotic, hydrological and anthropogenic factors on fish abundance and distribution in natural run-of-the-river shallow lakes. River Research and Applications, 25(6): 713-733.

Shannon, C. E. \& W. Weaver. 1949. The mathematical theory of communication. Urbana, University of Illinois Press, 117p.

Siragusa, A. 1964. Geomorfología de la Provincia de Buenos Aires. Buenos Aires, Sociedad Argentina de Estudios Geográficos, Anales Tomo XII.

Smith, C. L. \& C. R. Powell. 1971. The summer fish communities of Brier Creek, Marshall County, Oklahoma. American Museum Novitates, 2458: 1-30.

Súarez, Y. R. \& M. Petrere Júnior. 2007. Environmental factors predicting fish community structure in two neotropical rivers in Brazil. Neotropical Ichthyology, 5(1): 61-68.

Thormälen de Gil, A. L. 1949. Estudio biológico y experimental de las adaptaciones (eurihalinidad) del pez vivíparo Jenynsia lineata. Revista del Museo de La Plata, Nueva Serie, Zoología, 5: 441-540. 